J. Product. \& Dev., 24(4): 831 - 850 (2019)

\title{
EFFECT OF PLANTING DATE AND FOLIAR FEEDING ON PRODUCTIVITY AND FRUIT QUALITY OF EGGPLANT
}

\author{
M.M.A. Ramadan ; Fayza, M. A. Darwesh and O.A. El-Zeiny \\ ${ }^{1}$ Hort. Res. Inst. Agric. Res. Center, Egypt. \\ e.mail.:
}

\section{ABSTRACT}

A factorial experiment (2 transplanting dates X 3 foliar feeding levels) in split plot design was conducted at Gemmeiza Agric. Res. Station, Gharbeya Governorate, Egypt during 2016 and 2017 growing summer seasons aiming to evaluate effects of transplanting date and foliar feeding with NPK and their interactions on growth, productivity and fruit quality of eggplant (Solanum melongena L,) c.v. Black Beauty. The two tested transplanting dates were summer transplanting on April and late summer on June. While, the three examined foliar feeding levels were spraying with tap water as control, spraying with Potassium-F fertilizer at rate of $3 \mathrm{ml} / \mathrm{L}$ or with Raizante fertilizer at rate of $2 \mathrm{ml} / \mathrm{L}$. Foliar spray was done three times throughout growing season.

Summer transplanting (April) significantly increased plant height, branches and leaves numbers/ plant and leaf area. Also, leaf percentages of $N, P$ and $K$ as well as total chlorophyll content were increased in April transplanting. Finally, total fruit yield (Ton/ fed) and its quality, expressed as more contents of total soluble solids (\%) and total sugars (g/ $100 \mathrm{~g} \mathrm{D.W.)}$ and less contents of total phenols (mg/ $g$ D.W.) and acidity (\%) in fruit tissues, were significantly increased in April transplanting comparing to late summer transplanting (June).

Foliar spraying with Potassium-F at $3 \mathrm{ml} / \mathrm{L}$ or Raizante at 2 $\mathrm{ml} / \mathrm{L}$ significantly increased all the above mentioned growth traits and leaf chemical constituents and in turn resulted significant increases in total fruit yield/ fed comparing to unfertilized control plants. Also, spraying Potassium-F or Raizante significantly reduced fruit firmness $\left(\mathrm{kg} / \mathrm{cm}^{2}\right)$ and fruit contents of total phenols and titratable acidity, at the same time significantly increased total soluble solids, total sugars and $K(\%)$ in fruit tissues. Raizante spray was more effective than Potassium-F in enhancing plant growth and fruit yield and its quality. 
Conclusively: when transplanting date interacted with foliar feeding, different significant responses were found. In general, interaction treatment of summer transplanting (April transplanting date) $X$ foliar feeding with Raizante at $2 \mathrm{ml} / \mathrm{L}$ significantly increased plant growth traits and leaf contents of $N, P, K$ and chlorophylls. Such interaction treatment resulted in the highest total fruit yield/ fed with the highest quality (high total soluble solids and total sugars and less total phenols and acidity in fruits) comparing all other interaction treatments.

Key words: Eggplant, planting date, potassium-F, Raizante, growth, yield.

\section{INTRODUCTION}

Eggplant (Solanum melongena var. esculenta L.) is one of the most important crops grown during summer season in Egypt. It is known to be subjected to high temperature adverse effects when day and night temperatures exceed 20 to $25^{\circ} \mathrm{C}$ (Wien, 1997).

Transplanting date was found to be markedly affect vegetative growth (Helal and El-Sayed, 2000), plant yield and its quality of eggplant (AduDapaah et al., 1999; Bakheit et al., 2001; Salmasi et al., 2006). Transplanting date affects plant canopy development (plant growth, leaves No./ plant and area and age of green leaves) in relation to intercepted solar radiation throughout the crop season (Rinaldi and Vonella, 2006). Both inappropriate early or late transplanting dates led to decreases in root and shoot growth. Plant yield in the early transplanting date is highly affected by cold, while in late transplanting it is affected by shortened growth season Cakmakci and Oral (2001).

Minerals uptake by plant from soil solution is regulated by several factors including texture, moisture conditions, $\mathrm{pH}$, aeration and temperature of the soil (Mengel and Kirkby, 1987). According to Williams and Kafkafi (1998), during growth and development of tomato plant, soil potassium supply is seldom adequate to support crucial processes in plant tissues as sugar transport from leaves to fruits, enzyme activation, protein synthesis and cell extension that ultimately determine fruit yield and its quality. Thus, using a simulative dose of potassium through foliar application could be a simple solution to overcome potassium unavailability for plants tissues.

Several researchers demonstrated efficiency of mineral fertilizer for enhance eggplant growth, yield and quality. In this regard, Sawan and Rizk (1998) stated that applying NPK fertilizer to eggplant at intermediate (90:30:67) or high rate (120:60:90) improved growth characteristics, leaf 
contents of nitrogen and phosphorus, total fruit yield and average number of resulted fruits per plant. Mahmoud (2000) tested effects of foliar spray of orthophosphoric acid at 0.2 and $0.4 \%$ concentrations. He recorded increases in eggplant growth, total yield, dry matter and mineral contents of $\mathrm{N}, \mathrm{P}, \mathrm{K}$ and $\mathrm{Fe}$ in plants received $0.2 \%$ concentration. Shafeek (2003) indicated that the vigorous of eggplant growth, physical and chemical properties and fruit yield were associated with NPK mineral fertilization. When Michatoje and Buczkousha (2009) determined eggplant responses to different potassium sources $\left(\mathrm{KCl}, \mathrm{K}_{2} \mathrm{SO}_{4}\right.$ or $\left.\mathrm{KNO}_{3}\right)$ and doses $(8,16$ or $24 \mathrm{~g}$ per plant), found that adding potassium at $8 \mathrm{~g} /$ plant in form of $\mathrm{KNO}_{3}$ was exceeded the other tested $\mathrm{K}$ forms and doses in increasing plant highest, dry matter, fruit yield and its contents of vitamin C. Furthermore, Aminifard et al. (2010) found that application of nitrogen fertilizer at rate of $100 \mathrm{~kg} / \mathrm{ha}$ resulted in the highest average fruit weight and fruit yield. Recently, El-Nemr et al. (2015) found that morphological characters of eggplant plants (plant height, numbers of leaves and branches/ plant and leaves fresh and dry weights/ plant) and yield and its components were improved by bio-stimulators treatments.

Additionally, Helal and El-Sayed (2000) stated that spraying cowpea plants with Potassium--F (a commercial fertilizer containing $\mathrm{P}$ and $\mathrm{K}$ elements) increased plant growth, yield and its components, dry matter and protein content. When El-Ashry (2006) foliar sprayed sweet pepper plants three times with potassium in EDTA form at $0.5,1.0$ and $1.5 \mathrm{~kg} \mathrm{~K} \mathrm{~K}_{2} \mathrm{O}$ concentrations, he found that fresh and dry weights and early and total yield of plants were significantly increased with $0.5 \% \mathrm{~K}$ spraying comparing to the two other tested concentrations. Also on tomato plants, Hanafy et al. (2007) found that spraying plants under heat stress conditions with Biomagic (containing a mixture of amino acids) resulted in significant increases in total sugars, essential, non-essential and total amino acids in fruits. Peyvast et al. (2009) reported that foliar application of potassium phosphate at $4 \mathrm{~mm} / \mathrm{L}$ significantly increased phosphorus, nitrogen and potassium contents in leaves. Tantawy et al. (2009) mentioned that foliar spraying tomato plants with amino acids at concentrations of 2 and $3 \mathrm{~g} / \mathrm{L}$ increased plant height, leaf area, fresh and dry weights, total yield and average fruit weight as well as total chlorophyll content and potassium percentage in leaves. Similarly, Abbas and Marhoon (2015) mentioned that treating sweet pepper plant with amino acids at level $800 \mathrm{mg} / \mathrm{L}$ significantly increased plant height, number of branches/ plant and dry matter percentage of shoots.

However, to determine the appropriate planting date and the optimum fertilizer dose for maximizing eggplant plant growth, productivity and fruit quality. Such study was conducted aiming to evaluate to what extent 
transplanting date (summer or late summer transplanting), foliar feeding with NPK (spraying with potassium-F at $3 \mathrm{ml} / \mathrm{L}$ or Raizante at $2 \mathrm{ml} / \mathrm{L}$ ) and their interactions affect growth, productivity and fruit quality of eggplant (Solanum melongena $L$, ) c.v. Black Beauty.

\section{MATERIALS AND METHODS}

Two field experiments were conducted during the two successive summer seasons of 2016 and 2017 at Gemmeiza Agric. Res. Station, Gharbeya Governorate, Egypt aiming to evaluate effects of transplanting date and foliar feeding with NPK and their interactions on growth, productivity and fruit quality of eggplant (Solanum melongena L,) c.v. Black Beauty.

The experiment were set as a factorial experiment $2 \times 3$ (2 transplanting dates and 3 foliar feeding levels) in a split plot design with 3 replicates. Transplanting date was set in the main plots, whereas foliar feeding levels were distributed within the sub-plots. The experimental unit area was $14 \mathrm{~m}^{2}$ and each unit contained 5 rows with $4 \mathrm{~m}$ length for each and $0.7 \mathrm{~m}$ width. Seedlings were transplanted at $30 \mathrm{~cm}$ apart between plants on one side of the row. The physical and chemical properties of the experimental soil are presented in Table 1.

Table 1. The physical and chemical properties of the experimental soil during 2016 and 2017 seasons

\begin{tabular}{|c|c|c|c|c|c|c|c|c|c|c|}
\hline \multirow[b]{2}{*}{ Season } & \multirow{2}{*}{$\begin{array}{c}\text { Organic } \\
\text { matter } \\
(\%) \\
\end{array}$} & \multirow{2}{*}{$\begin{array}{l}\text { Clay } \\
(\%)\end{array}$} & \multirow{2}{*}{$\begin{array}{l}\text { Silt } \\
(\%)\end{array}$} & \multirow{2}{*}{$\begin{array}{c}\text { Sand } \\
(\%)\end{array}$} & \multirow{2}{*}{$\begin{array}{c}\text { Texture } \\
\text { class }\end{array}$} & \multirow{2}{*}{$\begin{array}{c}\text { EC } \\
\text { m.mohs } / \mathrm{cm}\end{array}$} & \multirow[b]{2}{*}{ pH } & \multicolumn{3}{|c|}{ Available (ppm) } \\
\hline & & & & & & & & $\mathbf{N}$ & $\mathbf{P}$ & $\mathbf{K}$ \\
\hline 2016 & 1.42 & 61.53 & 27.87 & 10.60 & $\begin{array}{l}\text { Clay } \\
\text { loam }\end{array}$ & 1.42 & 7.86 & 8.52 & 0.031 & 0.52 \\
\hline 2017 & 1.51 & 62.11 & 26.76 & 11.13 & $\begin{array}{l}\text { Clay } \\
\text { loam }\end{array}$ & 1.44 & 7.92 & 9.12 & 0.028 & 0.49 \\
\hline
\end{tabular}

The first tested transplanting date was summer transplanting on $1^{\text {st }}$ April, while the second one was late summer on $1^{\text {st }}$ June for the two experimental seasons of 2016 and 2017. However, eggplant c.v. Black Beauty seeds were sown in the nursery under plastic tunnels on $3^{\text {rd }}$ February for the summer transplanting date and on $3^{\text {rd }}$ April for the late summer transplanting date. Then, similar seedlings were transplanted under open field conditions on the above-mentioned transplanting tested dates during the two experimental seasons. 
The three examined foliar feeding levels were spraying with tap water as control, spraying with Potassium-F fertilizer at rate of $3 \mathrm{ml} / \mathrm{L}$ and spraying with Raizante fertilizer at rate of $2 \mathrm{ml} / \mathrm{L}$. Potassium-F fertilizer containing $0.0 \% \mathrm{~N}, 10 \% \mathrm{P}_{2} \mathrm{O}_{5}$ and $30 \% \mathrm{~K}_{2} \mathrm{O}$. While, Raizante fertilizer containing NPK in chelated form. Its analysis was $20 \%$ polysaccharides, $3.5 \%$ free amino acids, $2.4 \% \mathrm{~N}, 1.25 \mathrm{P}$ and $1.5 \% \mathrm{~K}$ (in $\mathrm{w} / \mathrm{v}$ for all percentages). Spraying was done with the examined concentrations three times at ten-day intervals beginning 30 days after transplanting date.

The meteorological data throughout the experimental period are shown in Table 2.

Table 2: Meteorological data of El-Santa region, Gharbeya Governorate during the experiment period from April to Oct. of 2016 and 2017

\begin{tabular}{|l|c|c|c|c|c|c|c|c|}
\hline \multirow{3}{*}{ Months } & \multicolumn{4}{|c|}{ 2016 season } & \multicolumn{4}{c|}{ 2017 season } \\
\cline { 2 - 9 } & \multicolumn{2}{|c|}{ Temperature $\left({ }^{\mathbf{O}} \mathbf{C}\right)$} & \multicolumn{2}{|c|}{ Humidity (\%) } & \multicolumn{2}{c|}{ Temperature $\left({ }^{\circ} \mathbf{C}\right)$} & \multicolumn{2}{c|}{ Humidity (\%) } \\
\cline { 2 - 9 } & Max. & Min. & Max. & Min. & Max. & Min. & Max. & Min. \\
\hline March & 25.7 & 15.0 & 73.4 & 32.2 & 20.6 & 9.6 & 81.0 & 79.0 \\
\hline April & 28.2 & 16.1 & 67.2 & 26.9 & 23.8 & 12.9 & 81.0 & 44.0 \\
\hline May & 31.3 & 19.7 & 67.4 & 26.3 & 27.2 & 15.5 & 82.0 & 43.0 \\
\hline June & 34.7 & 23.2 & 68.5 & 29.2 & 29.3 & 18.0 & 85.0 & 48.0 \\
\hline July & 34.4 & 23.5 & 81.0 & 33.1 & 31.9 & 20.4 & 86.0 & 50.0 \\
\hline August & 36.1 & 25.1 & 83.4 & 32.0 & 31.4 & 19.9 & 86.0 & 49.0 \\
\hline September & 33.2 & 22.7 & 80.2 & 30.7 & 29.6 & 18.3 & 84.0 & 46.0 \\
\hline October & 31.4 & 21.0 & 76.2 & 30.8 & 28.1 & 14.3 & 79.0 & 44.0 \\
\hline
\end{tabular}

Central Laboratory for Agricultural Climate (CLAC), Agricultural Research Center

(ARC), Ministry of Agriculture and Land Reclamation.

Max.: Maximum, Min: Minimum.

\section{Recorded Data:}

Vegetative growth:

Ten plants for each plot were randomly chosen after 65 days from transplanting (at the beginning of fruiting) to determine vegetative growth responses to different treatments. The vegetative growth was asses as plant height $(\mathrm{cm})$ and leaves and branches number per plant. In addition, leaf area $\left(\mathrm{cm}^{2}\right)$ of the fifth leaf (beginning the plant top) was recorded using a digital leaf area meter according to Watson (1958).

\section{Leaves chemical determinations:}

Total chlorophyll in fresh leaves was measured at flowering stage using Minolta Chlorophyll Meter SPAD- 502 according to Manje \& Bagbee (1992). 
In addition, leaves samples were also taken just before fruiting and were dried at $70{ }^{0} \mathrm{C}$ for 72 hours, finally ground and digested. Then, Nitrogen content was determined in the digested solution using modified Micro-Kheldahl method as described by Plummer (1971), Phosphorus was determined calorimetrically according to the method of Jakson (1973) and potassium was measured using flame photometer as described by Brown and Lilliand (1964).

\section{Fruit yield and its quality:}

Mature fruits were harvest regularly every three days and the cumulative yield per each plot over season was determined, then fruit yield (ton/ fed) was calculated for each treatment. Also the relative increases in yield (relative to the least value for each treatment) was calculated.

Fruit quality was determined at the known three fruit growth and development stages of eggplant; i.e., early stage (eaten or fresh marketing stage), turning stage (from fresh market stage to seed development stage) and full maturity stage (complete seed maturity inside the fruit). A five fruits at each maturity stage were randomly taken from each experimental plot for such determinations. Fruit quality determinations were included fruit firmness $\left(\mathrm{kg} / \mathrm{cm}^{2}\right)$ as physical property. Also, total soluble solids percentage was determined using a hand refrectometer according to the method described in the AOAC (1990). As well as total phenols (mg/g dry weight), total sugars (mg/100 $\mathrm{g}$ dry weight), reducing sugars $(\mathrm{mg} / 100 \mathrm{~g}$ dry weight) and total acidity were also analyzed according to the methods of Rosen (1957), Snel and Shell (1953), Dubois et al. (1956) and AOAC (1990), respectively. In addition, K percentage in eggplant fruit tissues was determined according to Brown and Lilliand (1964).

\section{Statistical analysis:}

All collected data were subjected to analysis of variance (ANOVA) and mean separation was done using least significant difference test (LSD) at 5\% level of probability according to Snedecor and Cochran (1980).

\section{RESULTS AND DISCUSSION}

\section{Vegetative growth:}

Vegetative growth responses to planting date, foliar feeding and their interactions were recorded in Table 3.

Transplanting date significantly affect all studied growth traits. It is clear that early transplanting date (summer transplanting on $1^{\text {st }}$ April) significantly increased vegetative growth expressed as plant height $(\mathrm{cm})$, 
branches and leaves numbers per plant and leaf area $\left(\mathrm{cm}^{2}\right)$ as compare to late transplanting date of late summer on $1^{\text {st }}$ June. These results are in agreement with the previous findings of Helal and El-Sayed (2000) and Suneetha et al. (2006). They mentioned that vegetative growth characters of eggplant were enhanced with summer planting comparing to late summer. However, This could be mainly due to the suitability of micro climate factors; i.e., temperature and relative humidity prevailing during the summer growing season (April planting date) that was favorable for nutrients uptake (Tables 6\&7). Thermo period (Table 2) refers to daily temperature changes. However, according to Cakmakci and Oral (2001) sugar beet plants produced maximum growth when exposed to day temperature that is about 10 to $15^{\circ} \mathrm{C}$ higher than night temperature.

Data represented effect of foliar feeding in Table 3 show that eggplant plants received three foliar sprays throughout the growing season with Potassium-F at $3 \mathrm{ml} / \mathrm{L}$ or Raizante at $2 \mathrm{ml} / \mathrm{L}$ recorded significant increases in plant height and branches and leaves numbers per plant as well as leaf area comparing to unfertilized control plants. Simultaneously, Raizante application was significantly exceeded Potassium-F; this was confirmed during the two tested seasons. Similar results were found by Tantawy et al. (2009); Khalel and Hado (2011) and El Sagan (2015). They found that foliar spraying of tomato plants with amino acids increased plant height, leaf area, and shoot fresh and dry weights.

Significant positive effects were noticed on the abovementioned growth characteristics (Table 3) when planting dates interacted with foliar feeding levels comparing to the same planting date without feeding. The most favorable beneficial interaction treatment was attained in summer planting (April planting date) interacted with foliar spraying with Raizante at rate of $2 \mathrm{ml} / \mathrm{L}$. Such interaction treatment recorded the tallest plants bearing the highest numbers of branches and leaves/ plant with more leaf area comparing to all other interaction treatments during the two experimental seasons. While, the least vegetative growth was noticed in plants planted in late summer and did not receive foliar feeding.

\section{Leaf chemical constituents:}

April transplanting significantly increased percentages of $\mathrm{N}, \mathrm{P}$ and $\mathrm{K}$ as well as total chlorophyll contents (SPAD) in eggplant leaf tissues comparing to late summer transplanting on June (Table 4). This was true during the two experimental seasons. Visually, Eggplant plants that planted in summer season produced dark green leaves more than plants that planted in late summer season. This might be related to thermal processes within 
plant tissue that often led to chlorophylls synthesis or degradation and result in colour changes (Canjura et al., 1991).

Significant increases in N, P, and $\mathrm{K}$ percentages and chlorophylls content in leaves of plants foliar sprayed with Potassiun-F or Riazante comparing to un-sprayed control plants. Raizante application was superior in this respect. This was obvious during 2016 and 2017 seasons (Table 4). Similar results were found by Jaafer (2012) on eggplant; Kazemi (2014) on tomato and El Sagan (2015) on cucumber, they recorded increases in leaf minerals contents after potassium fertilization.

Significant effects on leaf chemical constituents were recorded when planting date interacted with foliar fertilization (Table 4). The highest percentages of $\mathrm{N}, \mathrm{P}$ and $\mathrm{K}$ as well chlorophylls content were found in leaves of transplanted plants on April and foliar-sprayed three time during season with Raizante at $2 \mathrm{ml} / \mathrm{L}$. While, the least values in this regard were noticed in transplanted plants on late summer (June) without any foliar feeding. However, summer planting X Raizante spray interaction treatment enhanced plant vegetative growth (as mentioned above, Table 3), so the suitable micro environmental conditions during summer planting beside foliar fertilization might enhanced the interrelationships between growth and minerals uptake resulting more growth and more minerals uptake.

\section{Fruit yield and its quality: \\ Fruit yield}

Data in Table 5 reveal that summer season transplanting (April) resulted in significant increases in eggplant fruit yield as compare to late summer season transplanting (June). The increases in total yield attained $18.4 \%$ and $11.3 \%$ in plants transplanted in April relative to yield of plants transplanted in June during $1^{\text {st }}$ and $2^{\text {nd }}$ seasons, respectively. These results might be attributed to the favorable effect of appropriate climate (temperature and relative humidity and so on) during early summer growth period that resulted more vegetative plant growth (plant height, leaves and shoots No/ plant and leaf area, Table, 3) with high leaf contents of N, P, K and chlorophyll (Table 4) that induced more photosynthetic and minerals absorption rates. This in turn produced high carbohydrates in plant tissues that gave rise to more cell division and enlargement; this was reflected as producing more fruits yield (El-Zeiny, 2002).

Concerning effect of foliar applications, data of the same Table 5 showed that spraying plants with either Potassium-F at $3 \mathrm{ml} / \mathrm{L}$ or Raizante at $2 \mathrm{ml} / \mathrm{L}$ significantly increased fruit yield comparing to unfertilized control plants during $1^{\text {st }}$ and $2^{\text {nd }}$ seasons. More increases in yield were 
found in plants received Raizante comparing to those sprayed with Potassium-F. Sprayed plants with Raizante gained $20.1 \%$ and $17.9 \%$ relative increases in fruits yield over than control plants in $1^{\text {st }}$ and $2^{\text {nd }}$ seasons, respectively. This result was in agreement with previous findings of Tantawy et al. (2009) who stated that spraying plants with potassium-F increased tomato fruit yield. Mansour and Osama (2016) stated that potassium application promote photosynthesis processes in eggplant. However, the increase in fruit yield in fertilized plants was expected because the vital roles within plant tissues of the nutrient elements that supplied via fertilizer application.

The interaction treatments between transplanting dates and foliar application of potassium-F or Raizante had significant effects on fruit yield in both seasons (Table 5). It was found that the most significant favorable beneficial interaction treatment was obtained when eggplant transplanted during summer season (April transplanting date) and foliar sprayed with Raizante at rate of $2 \mathrm{ml} / \mathrm{L}$. The relative increases in total fruit yield were 39.3 and $32.3 \%$ for transplanted plants in April and sprayed with Raizante over the plants that transplanted in June and unfertilized in the $1^{\text {st }}$ and $2^{\text {nd }}$ seasons, respectively.

\section{Fruits quality:}

Fruit quality characteristics at the three fruit ripening stages of early stage (eaten or fresh marketing stage), turning stage (from fresh marketing stage to seed development stage) and full maturity stage (complete seed maturity inside the fruit) are recorded in Tables 6,7 and 8. It is obvious that fruit characteristics were varied during different fruit ripening stages.

Concerning transplanting date effects on fruit traits (Tables $6,7 \&$ 8 ), the confirmed results during the two experimental seasons showed that, generally, eggplant transplanted in summer season (April transplanting date) produced fruits with high quality expressed as containing high values of K (\%), total soluble solids (\%) and total sugars (g/ 100g D.W.) at different ripening stages. On the contrary, less quality expressed as higher values of fruit firmness $\left(\mathrm{kg} / \mathrm{cm}^{2}\right)$, titratable acidity $(\%)$, total phenols $(\mathrm{mg} /$ g D.W.) and reducing sugars (g/ $100 \mathrm{~g}$ D.W.) were attained with fruits of plants that transplanted in the late summer season (June plating date).

Data of the same Tables $6,7 \& 8$ showed that sprayed plants with Potassium $-\mathrm{F}$ at $3 \mathrm{ml} / \mathrm{L}$ or Raizante at $2 \mathrm{ml} / \mathrm{L}$ produced fruits with high quality especially at the early fruit ripening stage (eaten or fresh marketing stage) comparing to unfertilized control plants, and Raizante spray was more effective in this respect. Generally, spray with Potassium-F or 
Raizante significantly reduced fruit firmness $\left(\mathrm{kg} / \mathrm{cm}^{2}\right)$ and fruit contents of total phenols (mg/ g D.W.) and titratable acidity (\%), at the same time significantly increased total soluble solids $(\%)$, total sugars $(\mathrm{g} /$ $100 \mathrm{~g}$ D.W.) and $\mathrm{K}(\%)$ in fruit tissues.

Regarding effect of the interaction between eggplant transplanting date and foliar fertilization on fruit traits, there were significant differences in this regard (Tables 6, $7 \& 8$ ). Interaction treatment of summer transplanting (April planting date) $X$ foliar feeding with Raizante at $2 \mathrm{ml} / \mathrm{L}$ resulted in fruits containing high total soluble solids and total sugars and less of total phenols and acidity (fruits with good quality) comparing to other interaction treatments. This was true during the two tested seasons. Similar results on eggplant were found by Hussein and Mohamed (2017).

\section{In Conclusion}

From the obtained results of this research, it could be recommended that transplanting eggplant (c.v. Black Beauty) during summer season (April) and subjected plants, three times during growing season with 10 days intervals, to foliar spray with Raizante fertilizer (contained $4 \% \mathrm{~N}$, $1.25 \mathrm{P}$ and $1.5 \% \mathrm{~K}$ in chelated form $+20 \%$ polysaccharides, $3.5 \%$ free amino acids) at rate of $2 \mathrm{ml} / \mathrm{L}$. This interaction treatment significantly increased plant vegetative growth as plant height, leaves and shoots No./ plant and leaf area as well as leaf contents of N, P, K and chlorophylls, and this was reflected as more fruits yield with high quality (containing high total soluble solids and total sugars and less total phenols and acidity).

\section{REFERENCES}

Abbas, M.K. and Marhoon, I.A. (2015). Effect of foliar application of seaweed extract and amino acids on some vegetative and anatomical characters of two sweet pepper (Capsicum Annuum L.) cultivars. International Journal of Research Studies in Agricultural Sciences, 1(1): 35-44.

Adu-Dapaah, H.K., Singh, B.B. and Fatokun, C. (1999). A fasciuated mutantin Cow pea (Vigna Unguiculata L. Walp). Acta Agronomica. Hungarica, 47: 371-376.

Aminifard, M.H., Aroiee, H., Fatemi, H., Ameri, A. and Karimpour, S. (2010). Responses of eggplant (Solanum melangena L.) to different rates of nitrogen under field conditions. J. Central Eur. Agric., II (4): 453-458. 
A.O.A.C. (1990). Association of official Analytical chemists' methods of Analysis Washington, D.C. , USA.

Bakheit, N.I., Stigter, K. and Abdalla, A.T. (2001). Underground storage of sorghum as a banking alternative. Low Ext. Input Sust. Agric. Mag., 17(1): 13-XX.

Brown, J.D. and Lilliand, M. (1964). Rapid determination of potassium and sodium in plant material and soil extracts by photometry. Amer. Soc. Hort. Sci., 48: 341-346.

Canjura, F.L., Schwartz, S.J. and Nunes, R.V. (1991). Degradation kinetics of chlorophylls and chorophyllides. J. Food Sci., 56(6): 1639-1643.

Cakmakci, R. and Oral, E. (2001). Root yield and quality of sugar beet in relation to sowing date, plant population and harvesting date interactions. Turk. J. Agric. For., 26: 133-139.

Dubois, M., Smith, F., Gilles, K.A., Hammilton, J.K. and Robers, P.A. (1956). Colorimetric method for determination of sugars and related substances. Anal. Chem., 28 (3): 350-356.

El-Ashry, M.A. (2006). Physiological studies on sweet pepper in new reclaimed lands. Ph.D. Thesis, Fac. Agric., Munufiya Univ., Egypt, $112 \mathrm{pp}$.

El-Nemr, M.A., El-Bassiony, A.M., Tantawy, A.S. and Fawzy, Z.F. (2015). Responses of eggplant (Solanum melongena var. esculenta L.) plants to different foliar concentrations of some bio-stimulators. Middle East J. Agric. Res. (4): 860-866.

El Sagan, M.A. (2015). Effect of some natural extracts on growth and productivity of cucumber under sandy soil conditions. Int. J. Adv. Res., 3(9): 677-686.

El-Zeiny O.A.H. (2002). Using tissue culture as a tool for increasing the productivity of seedlings and total yield of some pepper hybrids. Arab Univ. J. Agric. Ain Shams Univ. Cairo, 10: 273-285.

Hanafy, A.H., Khalil, M.K., Metwally, A.M. and Abdelaziz, M.A. (2007). Effect of biomagic, yeast, acadion seaplants, foliafeed D, trial compound fertilizer, putrescine and silicon treatments on growth, yield and chemical composition of tomato plants grown under early and late summer seasons. J. Agric. Sci., Mansoura Univ., 32(2): 913949.

Helal F.A. and Soad, A. El-Sayed (2000). Growth, yield, germination, seedling vigor and seed quality of some couple cultivars as affects by sowing date and foliar nutrition with potassin- F and Novatrein. Zagazig J. Agric. Res., 27(4): 875-898. 
Hussein, A.H. and Mohamed, M.M. (2017). The response of white eggplant plants to foliar application with boron and potassium silicate . Assiut J. Agric. Sci., 48(1): 394-401.

Jaafer, H.S. (2012). Effect of potassium fertilizer (For Max) concentration levels and frequent sprayings on growth and crop yield of eggplant (Solanum melongena L.) grown in plastic house. Kufa J. Agric. Sci., 4(1): 186-195.

Jakson, M.L. (1973). Soil chemical analysis prentice-Hall of India private limited, New Delhi, India.

Kazemi, M. (2014). Effect of gibberellic acid and potassium nitrate spray on vegetative growth and reproductive characteristics of tomato. $J$. Biol. Environ. Sci., 8(22): 1-9.

Khalel, A.M.S. and Hado, E.K. (2011). The effect of applying extract of garlic, liquorice root and algaren on growth and yield of kidney bean (Phaseolus vulgaris L). $5^{\text {th }}$ Scientific Conference of College of Agriculture - Tikrit University, Iraq. 27 - 28 April, 2011.

Mahmoud, H.A.F. (2000). Effect of sulphur and phosphorous on some eggplant cultivars under calcareous Sol. Bull. Fac. Agric. Cairo Univ., 51: 209-226.

Mansour E.R. and Osama, A.A.S. (2016). Response of eggplant (Solanum melongena L.) to potassium and liquorice extract application under saline conditions. Acta Sci. Pol. Hortorum Cultus, 15(6): 279-290.

Michatoje, Z. and Buczkousha, H. (2009). Influence of varied potassium fertilization on eggplant yield and fruit quality in plastic tunnel cultivation. Folic Hort., 21(1): 17-26.

Manje, O.A. and Bugbee, B. (1992). Inherent limitations of nondestructive chlorophyll meters. A comparison of two types of meters. Hortscience, 27: 69-71.Peyvast, G., Olfati, J.A., RamzamiKharazi, P. and Kamari-Shahmaleki, S. (2009). Uptake of calcium nitrate and potassium phosphate from foliar fertilization by tomato.$J$. Hort. For., (1): 7-13.

Mengel, K. and Kirkby, E. A. (1987). Principles of Plant Nutrition. $4^{\text {th }}$ ed., International Potash institute. Norblafen-Bern, Switzerland.

Plummer, D.T. (1971). An introduction to practical biochemistry. Mc. Grow Hill Book Company, UK, 278 pp.

Peyvast G. , J. A. Olfati, P. Ramezani-Kharazi and S. KamariShahmaleki (2009). Uptake of calcium nitrate and potassium phosphate from foliar fertilization by tomato. J. Hort.Forestry, 1(1):7-13. 
Rinaldi, M. and Vonella, A.V. (2006). The response of autumn and spring sown sugar beet (Beta vulgaris L.) to irrigation in southern Italy. Water and radiation use efficiency field Crops Research, 95 (2-3): 103-14.

Rosen, H. (1957). A modified ninhydrin colormetric. Biochem. Biopsy, 57: $10-15$.

Salmasi, S., Ghassemi, G. and Moghbelli, S. (2006). Effect of sowing date and limited irrigation on the seed yield and quality of dill (Anethum Graveolens L.), Turk. J. Agric. Fori., 30: 281-286.

Sawan, O.M. and Rizk, A.F. (1998). The productivity of eggplant (Solanum melangena L.) as affected by the sulfur element and NPK mixture. Egyptian J. Hort., .25(1): 1-16.

Shafeek, M.R. (2003). Growth and yield of eggplant and its physical and chemical quality as affected by organic and mineral fertilizer. $J$. Agric. Sci. Mansoura Univ., 28: 2853-2866.

Snedecor, G..A. and Cochran, W.G. (1980). Statistical Methods. $7^{\text {th }}$ Ed., the Iowa State Univ., Press, Ames., Iowa, USA.

Snel, F.D. and Shell, C.T. (1953). Colorimetric Methods Of Analysis Including Some Turlidimetric And Nephelometric Methods D. Van Nastrad Co. Inc. Princeton. New Jersey, Toronto, New York, London, $666 \mathrm{pp}$.

Suneetha, Y., PAtel, J.S., Khatharia, B. Bhanvadia, A. S., Kaharia, P.K. and Patel, S.T. (2006). Stability analysis for yield and quality in Brinjal (Solanum melongena L.). Indian J. Genet., 66:4.

Tantawy, A.S., Abdel-Mawgoud, A.M., El Nemr, M.A. and Ghorra Chomoum, Y. (2009). Alleviation of salinity effect on tomato plant by application of amino acids and growth vegetables. European $J$. Sci. Res., 30(3): 484-494.

Williams, L. and Kafkafi, U. (1998). Intake and translocation of potassium and phosphate by tomatoes by 24 late sprays of $\mathrm{KH}$ PO (MKP). In: El-Fouly, M.M., F.E. Abdalla, and A.A. Abdel-Maguid (Eds). Proceeding of the Symposium on Foliar Fertilization: A technique to improve production and decrease pollution, Cairo, Egypt. 10-14 Dec. 1995, NRC, pp. 85-90.

Watson, D. J. (1958). The dependence of net assimilation rate on leaf area index. Annals of Botany, 22:37-54

Wien, H.C. (1997). The Physiology Of Vegetable Crops. CAB Int., 198, Madison, Av. New York, NY, USA. 10016-4341, pp. 125. 


\section{تأثير ميعاد الزراعة والتغذية الورقية على إنتاجية وجودة ثمار الباذنجان}

محمد محمد عبد اللطيف رمضان ، فايزة محمد درويش ، أسامه عبد المنعم الزينى

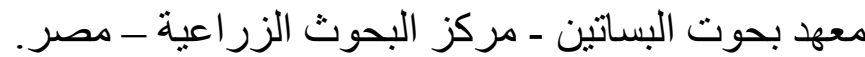

أجريت تجربه عامليه ( 2 ميعاد للثتل ×3 مستويات للتغذيه الورقيه) في نظام قطع منشقه

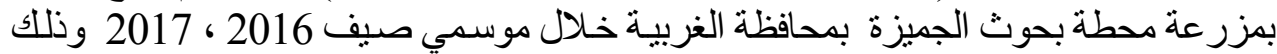

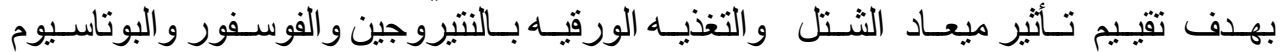

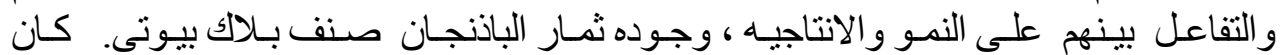

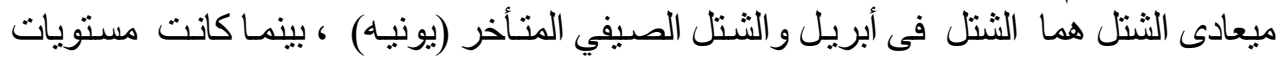

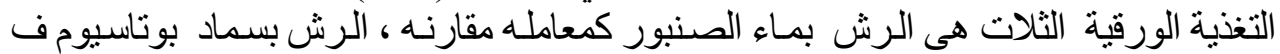

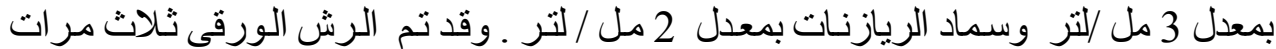
خلال موسم النمو.

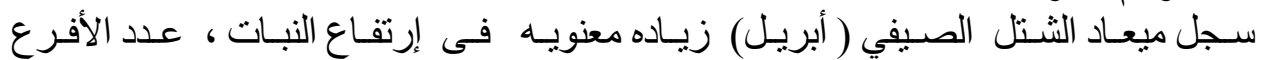

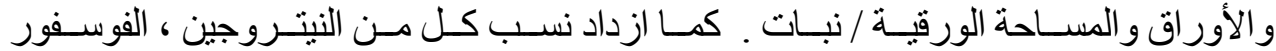

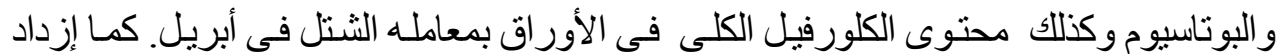

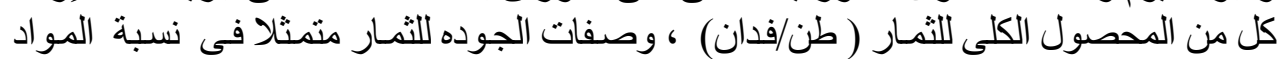

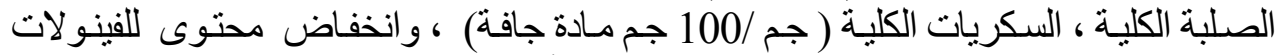

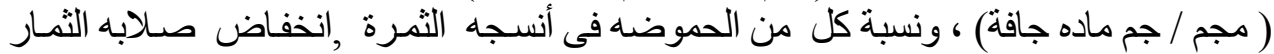

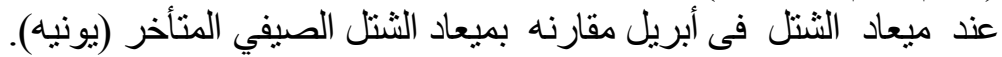

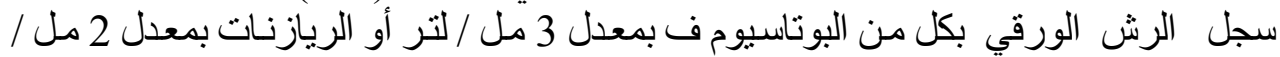

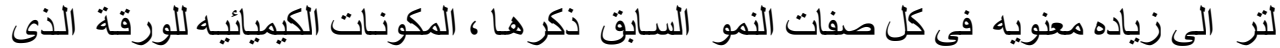

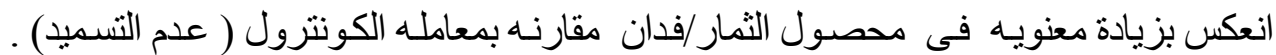

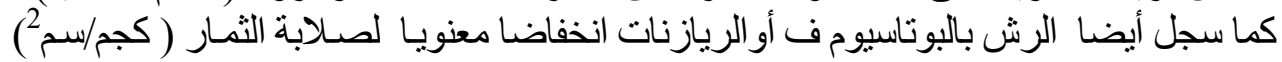

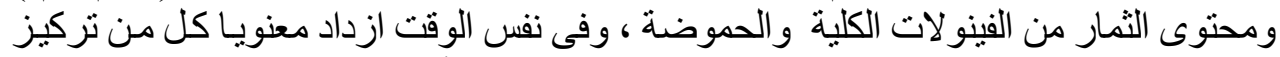

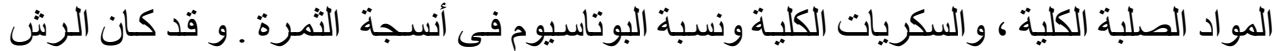

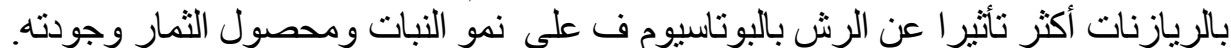

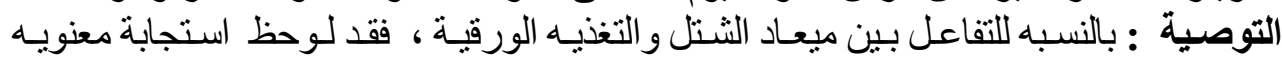

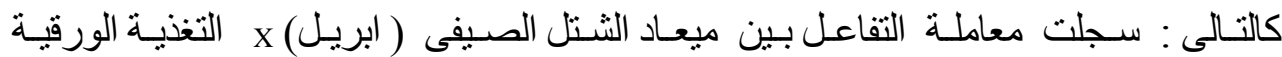

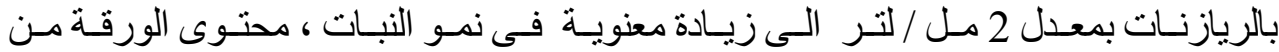

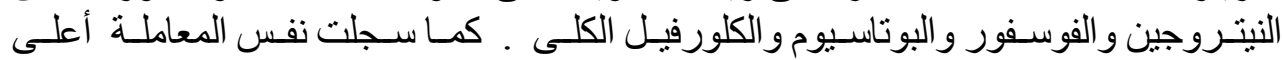

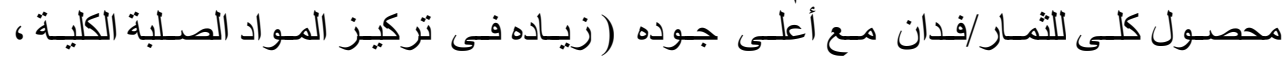

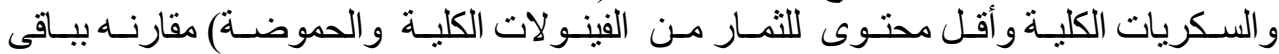

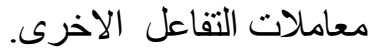

